Tér és Társadalom 3. évf. 1989/1. 100-107. p.

\title{
100
}

való állampolgári részvétel, ưj kreativitás és kockázatvállalás kibontakozása, végül, de nem utolsósorban a szolidáris gondolkodás, tervezés, cselekvés. Ez utóbbi követelmény a városlakókra, a központokban élökre, dolgozókra, a falvakban nemegyszer hétvégi házzal rendelkezőkre vonatkozik، hogy megszünjék, „,a falunak a város által való kizsákmányolása".

Összegezésként a konferencia két tanulságát emelem ki. Az egyik a Magyarország iránti megkülönböztetett érdeklődés, hazánk és Ausztria viszonyának felelös elem. zése, értékelése. Úgy tünt, Magyarország több figyelmet kap nyugati szomszédjától, mint amennyit mi fordítunk Ausztriára. Pedig elég sok tanulni valónk lenne szomszé. dainktól. A másik megjegyzésem ezzel is összefügg. Ausztriában hallottam az önironikus fogalmat: „Jammerkultur”. Ha a panaszkodás kultúrája a monarchia öröksége, akkor ebből az örökségből nekünk sokkal több jutott, mint egykori központunknak. A hasonló konferenciákon nálunk megszokott kilátástalan pesszimizmus, a hanyatlás és pusztulás képeinek ecsetelése helyett a problémák konstruktív kezelése volt jellemző, az elöadások és viták a korábban elkövetett hibák korrekcióját, az itt vagy amott bevált, sikeres gyakorlat elterjesztését, elemzését szolgálták. Ez az optimizmus természetesen nem táplálkozhatik Ausztria kivételesen szerencsés geopolitikai helyzetébỏl, forrása a társadalomnak és az egyénnek a saját cselekvőképességébe és jövőjébe vetett hite, közösségi felelósségérzete. Talán elsösorban ezt kellene megtanulnunk szomszédunktól.

\section{KISS ATTILA:}

\section{TÉRSZERKEZETI TERMINOLÓGIÁK AUSZTRIÁBAN}

A társadalmi-gazdasági térrel foglalkozó tudományok müvelöi - de bizonyára más területeken is hasonló a helyzet - sok esetben ugyanazt a fogalmat egymástól többé-kevésbé eltérö jelenségek megkülönböztetésére használják, illetve ugyanazt a jelenséget más-más kifejezéssel jelölik. A szakmai polémiák gyakran a fogalmak tisztázásával kezdódnek. Nincs ez másképpen Ausztriában sem. A térbeni jelenségek leírása során használatos fogalmak, több-kevesebb átfedéssell, de három terminológiai rendszert épitsenek fel, melyek jelenleg a tudományok osztrảk müvelöi körében használatosak.

Az egyik a "központi helyek” elméletének HANS BOBEK nevével fémjelzett ausztriai adaptációja, a másik a jelenleg is érvényben levő osztrák területrendezési koncepció (ÖRK) modellje és a harmadik a statisztikai összesítések alapját képező - az Osztrák Központi Statisztikai Hivatal által kidolgozott - ún. „városrégiók” rendszere.

Részben elméleti, részben módszertani szempontból nem felesleges - még ha vázlatosan is - a három szisztémát áttekinteni. 


\section{A „központi helyek" rendszere}

A társadalmi-gazdasági térszerkezet feltárása Ausztriában is több évtizedes kutatási előzményekre épül. Az ide vonatkozó kutatások kiindulópontja az a ma már triviálisnak tưnơ gondolat, hogy a nem mezógazdasági tevékenységek koncentrációja bármely társadalmon belül - W. CHRISTALLER 1933-ban megjelent munkája nyomán „központi helyek"-nek nevezett - településcentrumok szükségszerü kialakulásával jár. Ezek a központi helyek funkcionális rangjuk függvényében kisebb-nagyobb terület népességének ellátását vállalják, s így szerepük, jelentőségük eróteljesen kiemelkedik környezetükbőii. A centrumok feltérképezésében és ellátási körzetük lehatárolásában meghatározó fontosságú $\mathrm{H}$. BOBEK és munkatársainak - kezdetben $\mathrm{H}$. HELCZMANOVSZKY, majd késöbb M. FESL - tudományos tevékenysége.

A modell lényege kettós. Egyrészt a különbözó fokozatú központi helyek megállapítását célozza, másrészt a hozzájuk tartozó el térơ szintú ellátási körzetek határainak megrajzolására törekszik.

1. táblázat

\section{A különbözö „központi helyek" rangjuk szerinti sorrendben}

\section{Eredeti elnevezés}

Zentrale Orte der unteren Stufa

$$
\left.\begin{array}{lr}
\text { - schwach (1) } \\
\text { - massig } & (2) \\
\text { - gut } & (3)
\end{array}\right\} \text { ausgestattet }
$$

Zentrale Orte der mittleren Stufa

- schwach (4)

- massig (5) ausgestattet

- gut (6)

Vierte/shauptstadt (7)

Landeshauptstadt

$$
\left.\begin{array}{ll}
\text { - schwach (8) } \\
\text { - gut } & \text { (9) }
\end{array}\right\} \text { ausgestattet }
$$

Bundeshauptstadt (10)
Magyar megfelel6

gyengén (1), mérsékelten (2), illetve jól (3) ellátott alsofokú központok

gyengén (4), mérsékelten (5), illetve jól (6) ellátott

középfokú központok

tartományon belüli körzetközpont (7)

gyengén (8) illetve jól (9) ellátott

tartományi székhely

fóváros (10)

A központi helyek környezetében ún. Potentieller Bereiche (POT) der unteren-, mittleren- und Virtelshauptstadtstufe lehatárolására nyilik lehetőség. Magyarra ezek a kifejezések az alsó-, közép- és felsőfokú központok ellátási területeként értelmezhetớk, és alsó-, közép- és felsöfokú vonzáskörzetként fordithatók.

A központok és körzeteik kijelölése minden egyes településbe kiküldött kérdőivek felhasználásával történt. Ezek a kérdóivek fokozatonként (alsó-, közép- és felsószintú ellátás) 12-13 kérdést tartalmaztak arra vonatkozóan, hogy az adott település lakói a különbözó szintû szolgáltatások igénybevételekor, illetve különböző áruk 
 \\ KISS ATTILA: \\ TÉRSZERKEZETI TERMINOLÓGIÁK AUSZTRIÁBAN \\ Tér és Társadalom 3. évf. 1989/1. 100-107. p.}

102

vásárlásakor melyik centrumot keresik fel. Igy a centrum körül többnyire egyértelmüen sikerült megállapítani az alsó-, közép- és felsőszintü eliátási körzeteket. Végül az igy kapott központi hely hálózat szolgált kiindulási alapul a további specifikus vizsgálatokhoz a lakosság társadalmi-gazdasági struktúrájáról, a területi népességvál tozás komponenseiröl, az idegenforgalmi centrumokról stb.

A részben közigazgatási funkció, részben ellátottság alapján rangsorolt központi helyeket (ld. 1. sz. táblázat) a szerzők még különböző funkcionális típusokba is rendezték, s igy a foglalkoztatottsági struktúra alapián a következő változatok megkülönböztetésére nyilt lehetőség:

1. túlnyomóan szolgáltató centrum,

2. vegyes, ipari és szolgáltató centrum,

3., illetve 4. ipari és bányászcentrumok, valamint igen jelentős ipari holyek központi funkcióval,

5. idegenforgalmi hely központi funkcióval,

6. szatellit-települések.

Így a modellen belül rangjuk, valamint funkcionális típusuk alapjân a települések igen széles skálában való osztályozására van mód.

\section{A területrendezési koncepció rendszere}

Miután 1955-ben a Belvedere-palota márványtermében a győztes hatalmak, valamint Ausztria képviselői aláirták a semlegességi államszerződést és a megszálló csapatok kivonultak az ország területéról, megszülethettek az első átfogó területfejlesztési intézkedések. Az ekkor elindult folyamat meghatározó mérföldköve 1971. Ekkor - pontosabban február 25-én - ült össze az Osztrák Területrendezési Konferencia (ÖROK) alakuló ülése, mely alapvetöen a szövetségi állam, a tartományok, valamint a települések közös szervezete. Mintegy évtizedes munka gyümölcseként, 12. ülésén, 1981. június 29-én fogadta el a szervezet ,az osztrák térszerkezet fejlesztési elképzelése"'-ként az Osztrák Területrendezési Koncepciót (ÖRK).

2. táblázat

\section{Az Osztrák Területrendezési Koncepció fogalomrendszere}

Eredeti elnevezés

Konzeptregion

Zentrale Konzeptregion

Periphere Konzeptregion

Ballungsraumgebiet

- Ballungskerngebiet

- Ballungsrandgebiet
Magyar megfelelő

Fejlesztési területegység, fejlesztési régió. Többé-kevésbé a magyar városkörnyék fogalmával azonosítható.

Központi helyzetú régio. Budapest, valamint a megyeszékhelyek környezetével azonosítható.

Periférikus helyzetú régió. A központi helyzetü régiók közötti tér.

Agglomerációk, agglomerálódó térségek.

- Az agglomeráció magja

- Az agglomeráció peremterülete 
Tér és Társadalom 3. évf. 1989/1. 100-107. p.

Eredeti elnevezés

Überganasgebiet

Landliche Raum

Höhere Zentren

Mittlere Zentren

\section{Magyar megfelelö}

Átmeneti terület, „köztes tér”. Az agglomerációk és a periférikus helyzetú régiók közötti terület.

Vidék. Nem azonositható a falusi térrel, mivel a kifejezés az agglomerációk közötti terület megnevezésére használatos, ahol városi települések is találhatók!

Felsöfokú központok. Ausztriában Bécs, a tartományi székhelyek, valamint az ún. „Viertelshauptstadt"-ok (tartományon belüli egyéb központok, mint pl. Stájerországban Leoben) tartoznak ide. Magyarországon Budapest és a megyeszékhelyek, illetve néhány korábban részleges felsófokú központok, nevezett városunk, mint pl. Dunaújuáros tekinthető a megfelelőjének.

Középfokú központok, melyek Ausztriában legalább 25 ezer lakosúak kell hogy legyenek.

Az ÖRK kidolgozása során az egyes fejlesztési területegységek, fejlesztési régiók meghatározásának alapvetően két kritériuma volt. Egyrészt a napi inga-vándorforgalom, másrészt az ellátási kapcsolatok, mint pl. oktatás, bevásárlás, kulturális intézmények, illetve hivatalok látogatása. Az így kapott fejlesztési régiók követik a közigazgatási határokat (ezek az ún. „Politischer Bezirk”-ek azonosíthatók a nálunk korábban megszüntetett járásokkal), hacsak a munkaerömozgás annak további felosztását nem teszi szükségessé.

Annak függvényében, hogy a naponta ingázók mekkora hányada lakik az elviselhetőnek tartott időtávolságon belül, a fejlesztési koncepció központi és periferikus fejlesztési régiók megkülönböztetését tartja szükségesnek. Az elviselhetőnek tartott ingázási távolságok határértékeit pedig a központ rangjától teszi függővé. Igy, a fơváros esetében 60 percet, a tartományi székhelyeknél 50 percet, más jelentősebb centrumoknál pedig 40 percet tekint elfogadhatónak. Amennyiben a lakosság több mint háromnegyed része a felsőfokú centrum elviselhetőnek tartott ingázási távolságán belül lakik, a területet központi régiónak, ellenkezó esetben pedig periferikus régiónak minósíti a koncepció.

Mint látható, a fejlesztési régiók az egyes központi funkciókat ún. „központi helyek" vonzáskörzeteinek tekinthetők.

A nagyobb települések körül kialakult népességtömörüléseket a koncepció külön kezeli, és „Ballungsraum”-oknak (agglomerációknak) nevezi. Pontosabban az elnevezés az olyan térséget hivatott környezetétól megkülönböztetni, ahol meghatározóak a városi életkörülmények és ahol a népesség, valamint a gazdasági tevékenység foIyamatos koncentrációja jellemzó. Hatása túlterjed a közigazgatási határokon is és vonzásereje következtében újabb és ujjabb funkciókat olvaszt magába. Az agglomeráción belül megkülönböztethetó egy magterület, magas népsürüséggel és sürū beépitettséggel, valamint egy peremterület, ahol egyre eróteljesebb a városiasodás folyamata.

A területrendezési elképzelés fogalomrendszere szerint a központi régióknak 
azon területeit, melyek az agglomerációkon kívül esneḱ, kevésbé városiasak, de még az elviselhetó ingázási távolságon belül vannak - átmeneti területnek tekintik. Ezt is, de egyébként az összes agglomerációkon kívül esó területet vidékként kezeli a koncepció, ahol a középfokú centrumok közül közel negyvenet, mint fejleszthetó centrumot külön ki is emel. Itt infrastruktúrafejlesztéssel, beruházások támogatásával a település attraktivitását kívánják növelni, s ily módon javítani a környék lakosságának életkörülményeit.

Ausztria területrendezési koncepciója végeredményben ennek a fogalmi körnek a segítségével készült el, és kidolgozói ennek felhasználásával állították össze azt a "célkatalógus"-t, mely mintegy tíz évre összefoglalja az ország területfejlesztési elképzeléseivel kapcsolatos teendరket.

\section{A Statisztikai Hivatal fogalomrendszere}

A 70-es években több ipari állam városfejlódésének tendenciájában fordulat következett be. Számos agglomeráció esetében a népességszám csökkenni kezdett és más, az agglomerációhoz közelebb fekvó területek kezdtek dinamizálódni. Igaz, a folyamat fơként az Egyesült Államokban mutatkozott eróteljesen, ám számos európai agglomeráció esetében is kitapintható már ugyanez a jelenség.

Jelentkezik-e ez a folyamat az osztrák városfejlódésben, és ha igen, akkor hogyan? A kérdés megválaszolásához nemcsak adatok, hanem egy olyan fogalomrendszer is szükséges volt, mely segitségével a probléma részletes vizsgálatát el lehet végezni. Mivel azonban a település mint statisztikai fogalom, mint statisztikai egység a téma szempontjából nem kielégító információforrás, így született meg az Osztrák Központi Statisztikai Hivatal ún. , városrégió-koncepcióo"-ja.

A koncepció kialakitásához nemcsak a lakosságra, a foglalkoztatottakra és az ingázókra vonatkozó statisztikai elemzések, hanem 1976 és 1979 között készített légifelvételek is támpontul szolgáltak. A jelenlegi koncepció két lépésben készült el, elóször az 1971-es, majd némi módosítással az 1981-es népszámlálás adatainak felhasználásával.

3. táblázat

$$
\text { A „városrégio-koncepcio" fogalomrendszere }
$$

Eredeti elnevezés

Siedlungseinheit

Stadtregion

Kernraum

Aussenzone

Landgebiet
Magyar megfelelő

Településegység. Teljesen, vagy viszonylag erősen összeépült lakóhelyek csoportja.

Városrégió. A jelentósebb centrumok és az ơket környezö tér.

A városrégió magterïlete.

A magterületet körülvevớ kü/só zóna.

Vidéki, (itt már) falusi têrség. 
A városrégió meghatározása, illetve lehatárolása érdekében az eredeti és az új felfogás is az ún. településegységböl indul ki. A koncepció minden c̈sszefüggó, beépített zónát, mely a közlekedési vonalak mentén, akár a települések közigazgatási határán is átnyúlik, településegységnek tekint. Az elózetes vizsgálat az összes településegységböl csak azokat elemezte, melyekben legalább 5000 lakos él, illetve a nem mezógazdasági foglalkoztatottak száma meghaladja a 2500 föt. Az így kiválasztott településegységek közül végül összesen negyvenkettőt lehetett valamely városrégió magjának minösíteni. A koncepció ugyanis városrégiónak tekint minden fontosabb városias teret, ahol az összlakosság meghaladja a 15 ezer föt és rendelkezik városias településmaggal, mely legalább 10 ezer lakost számlál, vagy akár több, de egymással strukturálisan és funkcionálisan szorosan összefüggö centrummal, melyek együtt szintén egy városrégió magját képezhetik. Ez utóbbi esetben azonban teljesülnie kell annak a feltételnek, hogy az összlakosság száma meghaladja az ötezret, vagy a nem mezőgazdasági keresők száma a 2500-at. Ehhez a maghoz csatlakozik az ún. külsó zóna, mely azokból a településekböl áll, amelyek a magterülettel szoros függóségi viszonyban vannak, és ennek a szoros függöségi viszonynak az alsó határát a napi ingázók 25\%-os aránya fejezi ki.

A fenti kritériumoknak megfelelóen kiválasztott 42 városrégió közül a bécsiben él az ország népességének 27\%-a, a tartományi székhelyek városrégióiban $22,4 \%$-a, a többi városrégióban együtt pedig 17,1\%-a. Az osztrák népességnek tehát mintegy kétharmada (pontosan 66.5\%-a) az ily módon definiált városrégiókban lakik. Ugyanakkor megjegyzendő, hogy ezt az értéket az 1961-es adattal $(65,9 \%)$ egybevetve koncentráció, míg az 1971 -es adattal $(66,5 \%)$ összehasonlítva a városi és város környéki népességtömörülés folyamatának vége regisztrálható. Valójában a jelenségnek két összetevője van: a bécsi városrégióban tapasztalható jelentős dekoncentrációval szemben ugyanis a többi városrégióban, ha mérsékeltebb ütemben is, de a koncentráció folytatódik!

\section{IV. Összegzés}

A fentiekben ismertetett három fogalomrendszer jelenségtartalma azonos és egyértelmü. Mindhárom az urbanizációs és agglomerációs folyamat leírásáhcz, megértéséhez, sót a folyamat befolyásolásához kíván segítséget nyújtani. Az eltérő kifejezéseík azonban azonos jelenségeket takarnak. Ezek közül egyet feltétlen célszerü kiemelni Érdekes módon az agglomeráció fogalma az egvik koncepcióban (ÖRK) „Ballungsraum"-ként, a másikban "Stadtregie"-ként szerepel. Arra, hogy a kettő mégis szinoním értelmezésü, és azonos az agglomerációval, abból lehet következtetni, hogy mindkér koncepció azonos elméleti forrásra - R. GISSER és R. WURZEL munkáira - hivatkozik. Az azonosságot ugyanakkor bizonyítja az agglomerációk fejlesztésével kapcsolatos feladatokról elfogadott ÖROK dokumentum is, mely váltakozva, de ugyanabban az értelemben használja mindhárom kifejezést. Az azonosságot támasztja alá az azonos szerkezet is. A „Ballungsraum" és a városrégió felépítése is azonos, mindkettó egy magterületból és egy külső zónából áll, melyek értelmezése alapvetően egyező.

A másik megjegyzést a fogalmak definiálásával kapcsolatban célszerü tenni. Igen célirányos és a praktikumnak megfelelöen az egyértelmúségre való törekvés tükröződik mindhárom fogalomrendszeren, de különösen a harmadikon, amely egyben a leg- 
fiatalabb is. Mindössze néhány, de jól megválasz tott és számszerüsíthető jelenség - fö. leg az ingázás - alapján történik az egyes területi egységek - mint például a magterület és a külső zóna - lehatárolása, de az egyáltalán szóbajöhető „,településegységek" kiválasztása is. Jóllehet teljesen megbízható képet így a központok által „,besugárzott" területek kiterjedésére nem lehet kapni, mégis a makrofolyamatok - sót, bizonyos esetében a mikrofolyamatok - értékeléséhez és jellemzéséhez az igy szerzett információk is elegendök.

A harmadik megjegyzés az adatbázis alapegységére vonatkozik. A népességmozgás térbeni folyamatáról, helyzetéről kapott kép élességét nagyban javítja az, hogy az adatszolgáltatás alapegysége nem a közigazgatásilag lehatárolt település, hanem az ún. népszámlálási körzet, melybớl egy településben több is lehetséges. Igy, egy adott közigazgatási határon belül is nyomon követhetó a népességmozgás. Regisztrálható a magterület és a peremterület esetleg eltérő tendenciája is, ső́t magának a magterületnek a körülhatárolása is nagyobb pontossággal végezhető el. Ilyenformán az adatbázis finomítása minden bizonnyal hozzájárul az agglomerációs folyamatok mélyebb és alaposabb megismeréséhez.

\section{IRODALOM}

\section{A „központi helyek" rendszeréhez}

BOBEK, H.-FESL, M. 1967: Versorgung mit zentralen Diensten, Karte in Atlas der Republik Ósterreich, XII/1b, Wien.

BOBEK, H.-FESL, M. 1978: Oas System der Zentralen Orte Österreichs-Eine empirische Untersuchung, Wien-Köln.

BOBEK, H.-HELCZMANOVSZKI, H. 1963: Zentrale Orte und ihre Bereiche. In.: Atlas der Republik Österreich, XII/1. Wien.

CHRISTALLER, W. 1933: Oie Zentralen Orte in Süddeutschland. Jena.

FESL, M.-BOBEK, H. 1983: Zentrale Orte Österreichs II. Wien.

FESL, M.-BOBEK, H. 1986: Karten zur Regionalstruktur Österreichs-Ein Nachtrag zum Atlas der Republik Österreich, Wien.

\section{Az osztrák területrendezési koncepcióhoz}

ÖROK Raumordnungsbericht Wien 1975., 1978., $1981 ., 1984$.

Österreichisches Raumordnungskonzept, ÖROK Schriftenreihe Nr. 28. In.: ÖROK Vierter Raumordnungsbericht, Wien 1984.

WICHA, B. 1982: Das Österreichische Raumordnungskonzept. Einführung, Übersicht, Kurzdarstellung, Wien.

Zielverstellungen und wichtigste Massnahmen für idie Orchung und Entwicklung der Ballungsraume in Österreich. In.: Tatigkeit der ÖROK 1974-1977, Wien 1975.

\section{A .városrégiók" elméletéhez}

FINOL, P. 19B2: Volkszahiung 1981: Entwicklung der Stadtregionen, Statistische Nachrichten. Heft 7.

FUCHS, I. 1983: Oas Konzept des Österreichisches Statistischen Zentralamtes zur Bestimmung und Abgrenzung von Stadtregionen (Version 1971), Statistische Nachrichten, Heft 1.

FUCHS, I. 1986: Neufassung der Stadtregionen aufgrund der Volkszahlung 1981. Statistische Nachrichten, Heft 6. 
GISSER, R. 1971: Der stadtische Lebensraum in Österreich, IS. Information, Heft 10.

GISSER, R. 1986: Stadt und Umland - Entwicklungstendenzen aufgrund der Grosszahlung 1981. Berichte zur Raumforschung und Raumplanung, Heft 1-3.

Statistisches Handbuch für die Republik Österreich 1985.

WURZER, R. 1970: Verdichtungsgebiete und Hauptregionen in Ósterreich. In.: Strukturanalyse 